\section{PD-117小児期逆境経験と精神的健康の関係 一潜在クラス分析を用いた検討一}

$\bigcirc$ 中井 (松尾) 和弥 ${ }^{1}$, 福井 義一 ${ }^{2}$

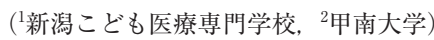

キーワード : 小児期逆境経験, 精神的健康, 潜在クラス分析

本研究では，潜在クラス分析により，小览期逆境経験（ACEs）を測定 する尺度の回答者を離散的なクラスに分類し，推定されたクラスにおけ る精神的健康度の違いについて検討することを目的とした。Lancers 社 のクラウドソーシングで募集された1729名（男性791名，女性938名）の データを分析に用いた。調查協力者には 10 種類の ACEs の有無と, 精神 的健康の指標としての抑うつ・不安症状などを測定する尺度を含んだ質 問紙調查を実施した。参加者を ACEs 尺度への回答パターンに基づいて 分類するために，潜在クラス分析を行い，最終的にブートストラップ尤 度比検定により 6 クラスを採用した。性別と年齢を統制変数，得られた 6 つのクラスを独立変数, 抑うつ・不安症状を従属変数とする重回帰分 析を行った。その結果, 全体の $70 \%$ 以上を占める ACEs の経験がほとん どないクラス 1 (と比較して，1つ以上の ACEs を有する可能性が高い 他の全てのクラスでは, 抑うつ・不安症状の得点が有意に高かった。本 研究から, ACEsを少しでも有する人 (クラス $2 \sim 6$ ) は, 全体の ACEs をほとんど有しない人よりも精神的に不健康であることが示された。

連絡先 E-mail : mcrsh059@yahoo.co.jp

PD-119 問題焦点型，情動焦点型，回避・逃 避型コーピングによるストレスへの 影響

○京角 幸祐 ${ }^{1}$, 石川 健介 ${ }^{1}$

(1 金沢工業大学)

キーワード：コーピング，ストレス反応，デイリーハッスル

本研究は, ストレス場面 (対人場面と課題場面), 経験したデイリー ハッスルの多さ, コーピングの種類 (問題焦点型, 情動焦点型, 回避 · 逃避型）が，ストレス反応の変化に与える影響について調べることが目 的であった。

北陸地方の大学生 107 名を対象に, 1 カ月の間隔を空けて 2 回の質問紙 調査を行った。1 回目では対象者の最も強くストレスを感じているスト レス場面とコーピングの種類，ストレス反応を，2回目では対象者が経 験したデイリーハッスルの多さとストレス反応を調べた。 1 回目と 2 回 目のストレス反応の差を，ストレス反応の変化量とした。2 回の調査に 漏れなく回答した対象者の内，ストレス場面について対人場面または課 題場面と答えた対象者を分析対象とした。

ストレス場面毎に，ストレス反応の変化量を従属変数、コーピングの 種類とデイリーハッスルの多さを独立変数とする分散分析を行った。結 果，対人場面では，情動焦点型に比べ，問題焦点型の方がよりストレス 反応を減少させていた。しかし, 課題場面と対人場面のどちらも, デイ リーハッスルの多さにおける有意差はなかった。デイリーハッスルとコー ピングの関連について，詳しく調べる必要があると考えた。
PD-118

対話による「自己の在り方」と「社

会・組織とのつながり」の模索一人 材開発プログラムの効果測定一

○竹田葉留美

(1 八洲学園大学 $)$

キーワード：自己の在り方，プログラム開発，効果測定

【問題と目的】自己の在り方と社会・組織とのつながりをもち，より生产 性を高めていくための人材開発プログラムの効果測定を目的とする。

【方法】参加者19名（女性 4 名 男性15名 平均年齢：49.08歳 $S D$ : 7.85）を対象に, プログラムの前後に質問紙による調查を行った。調查 内容は, デモグラフィック要因, 心理的要因（自尊感情, 多元的共感性, セルフモニタリング, ワークエンゲージメント), 主観的ストレスにより 構成。【結果】心理的要因のプログラム前後の平均值の差の検定を行った ところ，プログラムの前後で主観的ストレス反応以外の，心理的変数の 間に有意な差が確認された（自尊感情 : $t(18)=3.38, p<.001$, 多元的共 感性 : $t(18)=3.14, p<.001$, セルフモニタリング $: t(18)=4.01, p<.001$, ワークエンゲージメント : $t(18)=2.99, p<.001$, 主観的ストレス反応 : $t(18)=2.10$, n.s. $)$ 。プログラムを行うことによる心理的要因の増高が確 認され，プログラムの効果が示唆された。【考察】心理的安全性が保たれ た中でプログラムを行うことが，心理的要因にポジティブな影響を与え たと考えられる。今後は, 対象の母集団を変えてさらなるデー夕を蓄積 していくことが必要である。
○菅 英恵 ${ }^{1,2}$, 朴 啓彰 $2, \#$, 熊谷 恵子 ${ }^{3}$

(1交通事故総合分析センター, ${ }^{2}$ 高知工科大学, ${ }^{3}$ 筑波大学)

キーワード : 成人期の ADHD 自己記入式症状チェックリスト, 脳の構造, 健常成人

本研究では, 脳ドッグを受診した一般健常者の男女（23歳〜 76歳, $N=$ 2,270）を対象に, 全157の脳領域の体積（頭蓋内体積で補正）と, ASRSpart 2 全12問の探索的因子分析結果から確認した(1)多動性・衝動性傾向 スコア ( 4 問), (2)不注意傾向スコア ( 4 問) との関係について重回州分 析を行った。年齢, 性別（1男性０女性）は交絡因子として処理した。 結果(1)多動性・衝動性が強い者は，有意に灰白質容量は少ないが白質容 量は大きいことが分かった。また, 左側では眼窩部 (下前頭回), 三角部 (下前頭回), 縁上回, 楔前部, 前部帯状回, 後部島, 被殼など, 右側で は中央弁蓋部, 上前頭回, 嗅内領域など, 両側では直回, 内側前頭前野, 梁下野, 側頭平面などの領域が有意に小さかった。(2)不注意が強い者は, 左側では前頭極の領域が有意に小さく，右側では海馬，側脳室内の領域 が有意に大きいことが分かった。多動性・衝動性傾向と不注意傾向では 関連する脳領域が異なっていたことが示唆された。

連絡先 E-mail : h_kosuge@itarda.or.jp 